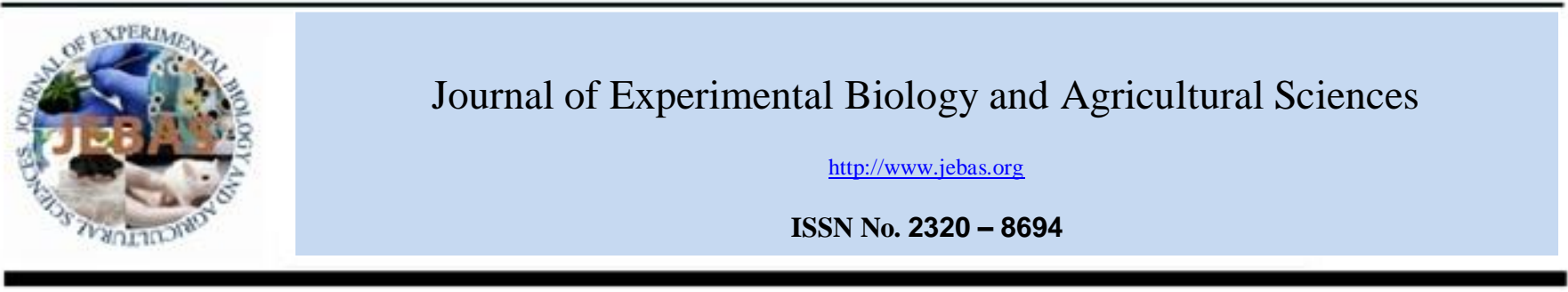

\title{
EFFECTS OF GENETIC POLYMORPHISMS ON EGG PRODUCTION IN INDIGENOUS NOI CHICKEN
}

\section{Nguyen Trong $\mathrm{Ngu}^{1, *}$, Nguyen Hong Xuan ${ }^{2}$, Chau Thanh $\mathrm{Vu}^{1}$, Nguyen Trong $\mathrm{An}^{3}$, Tran Nhan Dung ${ }^{4}$ and Nguyen Thi Hong Nhan ${ }^{1}$}

\author{
${ }^{1}$ College of Agriculture and Applied Biology, Can Tho University, Can Tho, Vietnam \\ ${ }^{2}$ Faculty of Food Technology and Biotechnology, Can Tho University of Technology, Can Tho, Vietnam \\ ${ }^{3}$ National Chung Hsing University, 250 Kuo Kuang Rd., Taichung 402, Taiwan R.O.C. \\ ${ }^{4}$ Biotechnology Research and Development Institute, Can Tho University, Can Tho, Vietnam
}

Received - September 19, 2015; Revision - October 16, 2015; Accepted - November 18, 2015

Available Online - December 15, 2015

DOI: http://dx.doi.org/10.18006/2015.3(6).487.493

\section{KEYWORDS \\ Candidate gene}

PCR-RFLP

Total egg number

Noi chicken

\begin{abstract}
The aim of this study was to evaluate the genetic potential of candidate genes involved in egg yield of Noi chicken, a popular backyard chicken breed in the Mekong Delta of Vietnam with limited egg production. A total of 130 hens were individually stalled for daily egg record in 20 weeks. Feather samples were collected for DNA extraction and genotyping was carried out using PCR-RFLP method. Five genes, namely DRD2 (Dopamine receptor 2), IGF-I (Insulin-like growth factor I), NPY (Neuropeptide Y), VIP (Vasoactive intestinal polypeptide) and VIPR-1 (Vasoactive intestinal peptide receptor 1) were used in the present work. It was shown that allele frequencies of DRD2/BseGI, $\mathrm{VIP} / V s p \mathrm{I}$ and VIPR-1/HhaI polymorphisms were of great discrepancy in Noi chicken population and there were significant associations between genotypes and egg numbers $(\mathrm{P}<0.05)$. Furthermore, chickens carrying DD (NPY/DraI), CC (VIPR-1/TaqI) and CC (VIPR-1/HhaI) genotypes had highest egg production with 50.9, 49.8 and 50.4 eggs/hen/20 laying weeks, respectively. These results provide an alternative for breeding selection of Noi chicken towards improving egg production.
\end{abstract}

* Corresponding author

E-mail: ntngu@ctu.edu.vn (Nguyen Trong Ngu)

Peer review under responsibility of Journal of Experimental Biology and Agricultural Sciences.

Production and Hosting by Horizon Publisher (http://publisher.jebas.org/index.html).

All rights reserved.
All the article published by Journal of Experimental Biology and Agricultural Sciences is licensed under a Creative Commons Attribution-NonCommercial 4.0 International License Based on a work at www.jebas.org.

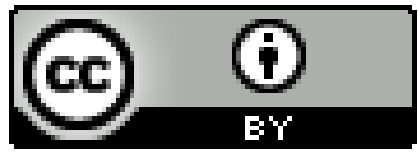




\section{Introduction}

Indigenous Noi chicken of the Mekong Delta possesses several desired characteristics including the ease of raising and high resistance along with some drawbacks such as low productivity and highly hybridized breeds (Quyen \& Son, 2008). Enhancing and stabilizing breeding quality are one of the methods used to improve these indicators. Many candidate genes associated with poultry productivity have been identified (Abdi et al., 2014; Fatemi et al., 2012; Xu et al., 2011a; Xu et al., 2011b), as a result of the unprecedented improvements of genetic technology, especially molecular genetics.

Various researches based on the increasing egg productivity have found that candidate genes such as DRD2 (Dopamine D2 Receptor), IGF-I (Insulin-like Growth Factor I), NPY (Neuropeptide Y), VIP (Vasoactive intestinal peptide) and VIPR-1 (Vasoactive intestinal peptide receptor 1) had significant effects on egg productivity. Chaiseha et al. (2003) cloned cDNA of the DRD2 gene in turkeys and pointed out the associations between DRD2 gene and production and hatching traits. Similarly, Xu et al. (2011a; 2011b) studied the g.5841629T $>C$ polymorphism on DRD2 gene and found a significant association between first laying age and total egg production in chickens at 300 days of age. For IGF-1 gene, Li et al. (2009) suggested that IGF-1 genetic polymorphism at position 5'UTR was related to egg production at 300 and 400 days of age and the number of continuous laying days. In addition, $\mathrm{Xu}$ et al. (2011b) also demonstrated the relationship between g.31394761C>T polymorphism of NPY gene and first-laying age in Ningdu Sanhuang chickens, followed by the publication of Fatemi et al. (2012) on the association between NPY gene and production traits as well as growth ability in many different chicken traits. Similarly, for VIP and VIPR-1 receptor genes, El Halawani et al. (2000) found that injecting VIP into 25 week and 54 week-old chickens resulted in an increase in egg production.
It can be therefore remarked that exploiting candidate genes to improve egg production is a potential strategy, yet will need to be examined in each group of chickens. Within the scope of this study, 8 polymorphism positions of the mentioned genes were used to assess their association with egg yield of Noi chicken.

\section{Materials and Methods}

The experiment was conducted on 130 Noi chickens raised at an experimental farm in Vinh Long province (Vietnam), where all hens were individually kept in cages. The hens in the period of laying eggs (28-47 weeks old) were mated with male Noi chicken at ratio of 1 cock: 8 hens. During the experiment, chickens were fed with diets having metabolizable energy of $2850 \mathrm{kcal} / \mathrm{kg}$ and $17 \%$ crude protein and all chickens were vaccinated before and during the experiment. The eggs laid were then collected and data were recorded daily during 20 weeks of laying.

Genotypes of candidate genes were determined by PCR-RFLP technique with some basic steps viz. extraction and purification of DNA from hen's feather (Nozawa et al., 1999); amplification of DNA by using appropriate primers corresponding to each gene; incubation of amplified products with restriction enzymes, and determination of the genotype by electrophoresis band on $2 \%$ agarose gel. Details of the primer sequences, annealing temperature, type of restriction enzyme used and size of PCR-RFLP bands are presented in Table 1.

Data on the frequency and chi-squared value were calculated using SNPStats program (Solé et al., 2006) (http://bioinfo.iconcologia.net/index.php). The association between genotype and egg production was analyzed based on General Linear Model of Minitab software version 16.0: $Y_{\mathrm{ij}}=\mu$ $+\mathrm{G}_{\mathrm{i}}+\xi_{\mathrm{ij}}$ (where $\mathrm{Y}_{\mathrm{ij}}$ : traits observed; $\mu$ : general mean, $\mathrm{G}_{\mathrm{i}}$ : Influence of genotype; $\xi_{\mathrm{ij}}$ : random error).

Table 1 Information regarding the polymorphisms studied

\begin{tabular}{|c|c|c|c|c|c|c|}
\hline Gene & SNP & Sequencing primer $\left(5^{\prime}-3^{\prime}\right)$ & $\operatorname{Ta}\left({ }^{\circ} \mathrm{C}\right)$ & Enzyme & $\begin{array}{l}\text { PCR-RFLP } \\
\text { size (bp) }\end{array}$ & References \\
\hline DRD2 & T5841629C & $\begin{array}{l}\text { F:tgcacataaaagcccactcactg } \\
\text { R: gcctgagctggtgggggg }\end{array}$ & 60 & BseGI & $\begin{array}{c}248 \\
196 / 52 \\
\end{array}$ & Xu et al., 2011a \\
\hline IGF-I & $\mathrm{C} 364 \mathrm{~T}$ & $\begin{array}{l}\text { F: actatacagaaagaacccac } \\
\text { R: tatcactcaagtggctcaagt }\end{array}$ & 60 & Pst $\mathrm{I}$ & $\begin{array}{c}621 \\
364 / 257\end{array}$ & $\begin{array}{l}\text { Nagaraja et al., } \\
2000\end{array}$ \\
\hline NPY & $\begin{array}{l}\text { AATA Indel } \\
\text { (I31391359D) }\end{array}$ & $\begin{array}{l}\text { F: tctcagagctccaacgtatga } \\
\text { R: atatttctgtgcctgaacaaca }\end{array}$ & 56 & DraI & $\begin{array}{c}248(252) \\
167 / 81 \\
\end{array}$ & Xu et al., 2011b \\
\hline NPY & C31394761T & $\begin{array}{l}\text { F: cgtggctgctttgcttcetttc } \\
\text { R: gggtacgaggcaaggacatg }\end{array}$ & 58 & KpnI & $\begin{array}{c}324 \\
200 / 124\end{array}$ & Xu et al., 2011b \\
\hline VIP & $\mathrm{C}+338 \mathrm{~T}$ & $\begin{array}{l}\text { F: gcttggactgatgcgtactt } \\
\text { R: gtatcactgcaaatgctctg }\end{array}$ & 55 & Hinf $\mathrm{I}$ & $\begin{array}{c}520 \\
480 / 40\end{array}$ & $\begin{array}{l}\text { Zhou et al., } \\
2010\end{array}$ \\
\hline VIP & $\begin{array}{l}\text { AGG Indel } \\
\text { (D2648-2650I) }\end{array}$ & $\begin{array}{l}\text { F: gaaacccatctcagtcatccta } \\
\text { R: accacctatttttccttttctac }\end{array}$ & 58 & $V s p \mathrm{I}$ & $\begin{array}{c}306 \\
154 / 152\end{array}$ & $\begin{array}{l}\text { Zhou et al., } \\
2010\end{array}$ \\
\hline VIPR-1 & $\mathrm{C} 1715301 \mathrm{~T}$ & $\begin{array}{l}\text { F:ctcctcaggcagaccatcatg } \\
\text { R:cttgcacgtatccttgggtagc }\end{array}$ & 61 & TaqI & $\begin{array}{c}486 \\
310 / 176 \\
\end{array}$ & Xu et al., 2011a \\
\hline VIPR-1 & $\mathrm{C} 1704887 \mathrm{~T}$ & $\begin{array}{l}\text { F:ccccgttaaactcagcagac } \\
\text { R:cccaaagtcccacaaggtaa }\end{array}$ & 61 & HhaI & $\begin{array}{c}434 \\
253 / 181\end{array}$ & Xu et al., 2011a \\
\hline
\end{tabular}

F: Forward primer; R: Reverse primer; Ta: Annealing temperature 


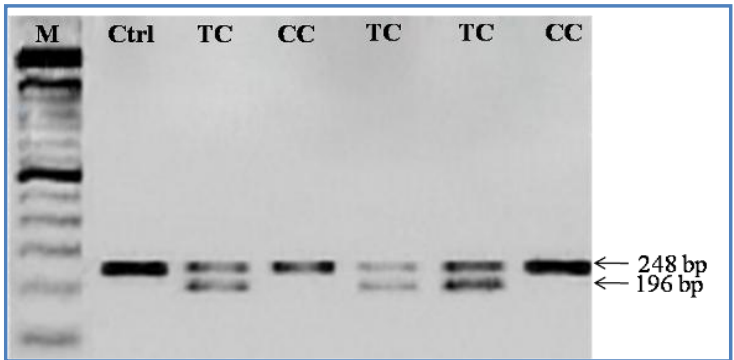

DRD2/BseGI

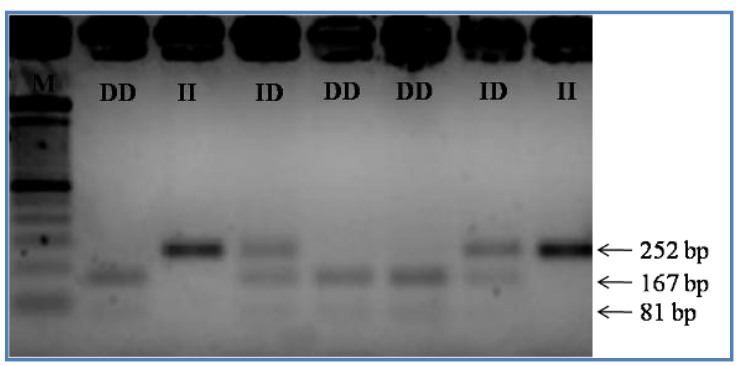

NPY/DraI

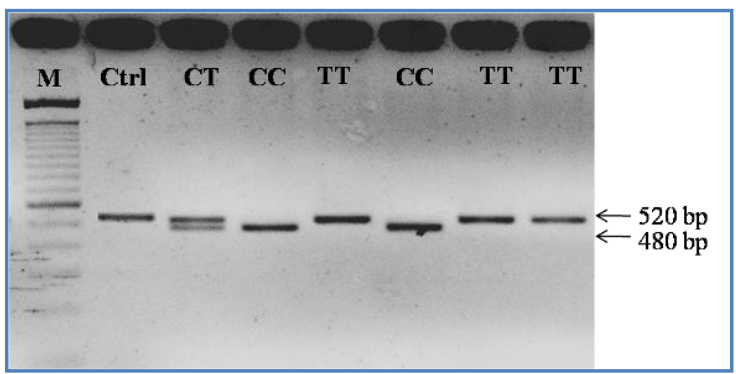

$\mathrm{VIP} / H i n f \mathrm{I}$

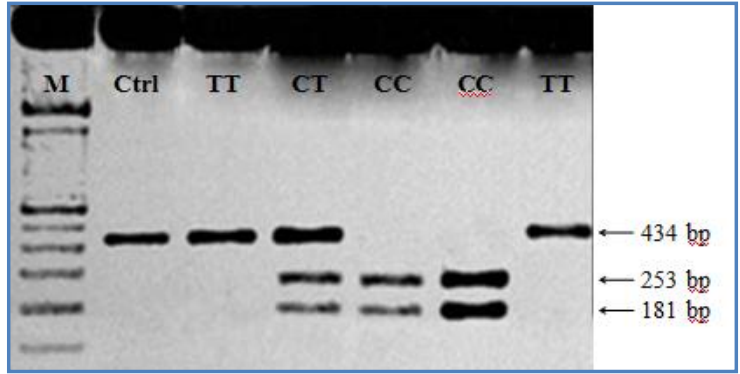

VIPR-1/TaqI

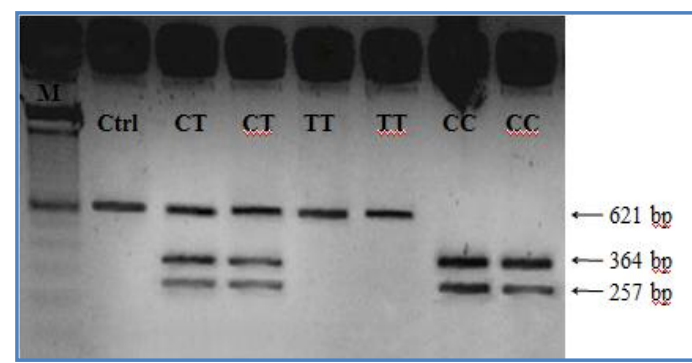

$\mathrm{IGF}-\mathrm{I} / P s t \mathrm{I}$

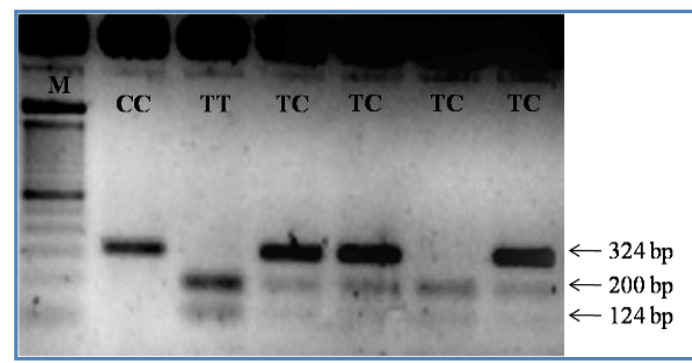

$\mathrm{NPY} / \mathrm{Kpn} \mathrm{I}$

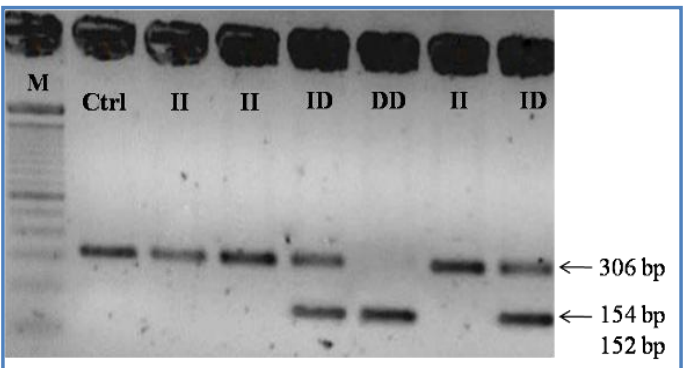

$\mathrm{VIP} / V s p \mathrm{I}$

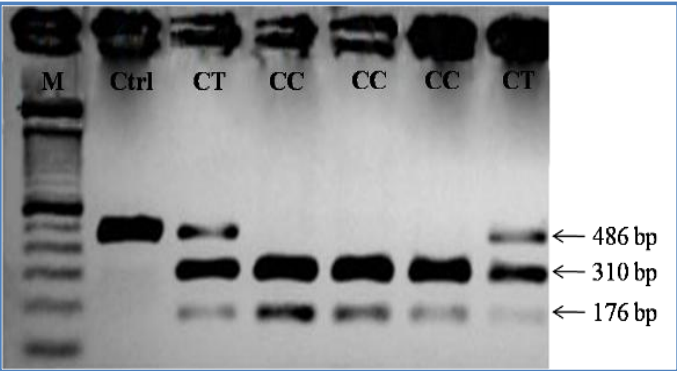

VIPR-1/HhaI

M : Standard DNA 100 bp scale (Fermentas); Ctrl: Non-incubated PCR products with restriction enzymes

Figure 1 Genotyping of different SNPs by agarose gel electrophoresis

\section{Results and Discussion}

In the current study, 6 Single Nucleotide Polymorphisms (SNPs) and 2 INDELs (Insertion/Deletion) for five candidate genes were identified from Noi chicken breed. The above SNPs were in transition mutations $(\mathrm{T}>\mathrm{C}$ or $\mathrm{C}>\mathrm{T})$, whereas 2 INDEL variations were based on the addition or removal of 4 AATA nucleotides (NPY/DraI) or 3 AGG nucleotides
(VIP/VspI). The number of bands and PCR-RFLP band size, genotype and allele frequencies of these polymorphism are shown in Figure 1 and Table 2. For the DRD2/BSeGI locus, the number of Noi chickens that had $\mathrm{T}$ allele accounted for a very low proportion of the population (0.12). Similar trend was found in other loci such as $\mathrm{C}$ allele $(0.21)$ (IGF-I/PstI) or $\mathrm{T}$ (0.22) (VIPR-1/HhaI) and the frequency of these mutations followed Hardy-Weinberg's law ( $\mathrm{P}>0.05)$. 
Table 2 Genotype and allele frequencies of polymorphisms.

\begin{tabular}{|l|c|c|c|c|c|c|c|}
\hline SNP & \multicolumn{9}{|c|}{ Genotype frequency } & \multicolumn{1}{c|}{ Allele frequency } & $\chi^{2}$ \\
\hline DRD2/BseGI & 123 & $0.01(\mathrm{TT})$ & $0.23(\mathrm{TC})$ & $0.76(\mathrm{CC})$ & $0.12(\mathrm{~T})$ & $0.88(\mathrm{C})$ & $0.49^{\text {ns }}$ \\
\hline IGF-I/PstI & 93 & $0.06(\mathrm{CC})$ & $0.29(\mathrm{CT})$ & $0.65(\mathrm{TT})$ & $0.21(\mathrm{C})$ & $0.79(\mathrm{~T})$ & $1.43^{\text {ns }}$ \\
\hline NPY/DraI & 130 & $0.22(\mathrm{II})$ & $0.42(\mathrm{ID})$ & $0.36(\mathrm{DD})$ & $0.43(\mathrm{I})$ & $0.57(\mathrm{D})$ & $2.38^{\text {ns }}$ \\
\hline NPY/KpnI & 123 & $0.20(\mathrm{TT})$ & $0.51(\mathrm{TC})$ & $0.29(\mathrm{CC})$ & $0.46(\mathrm{~T})$ & $0.54(\mathrm{C})$ & $0.03^{\text {ns }}$ \\
\hline VIP/HinfI & 107 & $0.12(\mathrm{CC})$ & $0.31(\mathrm{CT})$ & $0.57(\mathrm{TT})$ & $0.28(\mathrm{C})$ & $0.72(\mathrm{~T})$ & $5.55^{*}$ \\
\hline VIP/VspI & 118 & $0.58(\mathrm{II})$ & $0.4(\mathrm{ID})$ & $0.02(\mathrm{DD})$ & $0.78(\mathrm{I})$ & $0.22(\mathrm{D})$ & $3.64^{\text {ns }}$ \\
\hline VIPR-1/TaqI & 111 & $0.48(\mathrm{CC})$ & $0.33(\mathrm{CT})$ & $0.19(\mathrm{TT})$ & $0.64(\mathrm{C})$ & $0.36(\mathrm{~T})$ & $8.27^{\text {** }}$ \\
\hline VIPR-1/HhaI & 125 & $0.64(\mathrm{CC})$ & $0.29(\mathrm{CT})$ & $0.07(\mathrm{TT})$ & $0.78(\mathrm{C})$ & $0.22(\mathrm{~T})$ & $2.80^{\text {ns }}$ \\
\hline
\end{tabular}

:P<0.05; ${ }^{* *}: P<0.01 ;{ }^{n s}: P>0.05$

In the 2 INDEL variants, genotypic frequencies of VIP/VspI mutation did not follow the Hardy-Weinberg law $(\mathrm{P}<0.05)$ and comparable results were also found in other chicken populations. For example, on Ningdu Shanghuang breed, the frequency of $\mathrm{C}$ allele was higher than $\mathrm{T}$ allele in DRD2/BSeGI mutation point (Xu et al., 2010; Xu et al., 2011a; Xu et al., 2011b). In addition, Kim et al. (2004) showed that $C$ allele frequency (0.31) was lower than T allele (0.69) at IGF-I/Pst I polymorphic position in Ogol chicken, but on the same Madandaran chicken, the distribution of 2 alleles was relatively equal (0.51 and 0.49) (Abbasi \& Kazemi, 2011). In addition, a comparison of allele frequency on VIPR-1/TaqI polymorphism also pointed out that most of the experimental chickens in the population had a higher proportion of $\mathrm{C}$ allele.

The effects of polymorphic positions on egg production indicators are displayed in Table 3, in accordance to which the SNPs on NPY and VIPR-1 genes showed a significant association with the egg productivity of Noi chicken in 20 weeks of laying $(\mathrm{P}<0.05)$. The highest egg yield was reported in chickens with 4 nucleotides lost (AATA INDEL) at NPY/DraI locus or chickens with CC genotype at VIPR1/TaqI or VIPR-1/HhaI position (49.8 to 50.9 eggs). It should be noted that the frequency of this genotype was also in relatively high proportion ( 0.36 to 0.64$)$, which suggested that the process of natural selection had contributed to the improvement of laying productivity, thereby increased the proportion of beneficial alleles in populations. For the remaining polymorphisms of the current study, the effect of genotype on egg production was not significant $(\mathrm{P}>0.05)$.

An important neural regulator that affects reproductive function in mammals and birds is neuropeptide Y (Hilal et al., 1996). In chickens, experiments have shown that when injected into the brain, NPY stimulated intake, increased insulin secretion process and altered levels of certain hormones in the blood such as prolactin, thyrotropin and GnRH (reproduction hormone) (Willoughby \& Blessing, 1987; Kuenzel \& McMurtry, 1988). Although there are evidences that NPY may play a role in the regulation of hormone secretion mechanism mentioned above, the association between polymorphisms in this gene and egg production is less evident and depends heavily on each different population. Earlier, in a population of commercial laying hens, Dunn et al. (2004) discovered INDEL
(4 bp) mutation at $700 \mathrm{bp}$ position before the start of NPY gene transcription, but no relationship with the total number of eggs was found. Similar findings were also described by Fatemi et al. (2012) on the Iranian Mazandaran local breed; Xu et al. (2011b) on Ningdu Shanghuang breed and Abdi et al. (2014) on West-Azarbaijan native chickens. In contrast, the report of Li et al. (2009) suggested that NPY/DraI polymorphism affect the total egg count of 300 day-old Wengchang chickens, which is confirmed by the current study and this can be explained as NPY gene variations have different effects to chicken ovulation in different breeds (Dunn et al., 2004).

VIP gene regulates GnRH secretion in both humans and poultry (Christian \& Moenter, 2008; Li et al., 2009). The effects of VIP on the body depend upon VIPR-1 and VIPR2 receptors, in which VIPR-1 gene is considered selective support indicator to reduce hatchability and improve egg quality (Zhou et al., 2008a). Results from VIPR-1/HhaI polymorphism research on Noi chickens showed that chicken with CC genotype had the highest egg production yield. Research by Xu et al. (2011b) also found the influence of this polymorphism on total egg production of Ningdu Sanhuang laying chicken of 300 days, in which $\mathrm{C}$ allele benefited more in the selection process. Besides, Zhou et al. (2008b) previously reported a similar result in many different chicken populations; and a number of other research results as well showed that VIPR-1/TaqI polymorphism was closely associated with incubation time and the first laying age and individuals carrying CC genotype had a longer incubation period and earlier first laying age (Zhou et al., 2008a; Zhou et al., 2008b). Recently, Xu et al. (2011b) reported that chickens with CC genotype had lower total egg production after 300 days as compared with chickens carrying TT genotype. This also implied that egg production had a negative correlation with hatching time and therefore the two polymorphisms on VIPR-1 gene could be potential molecular markers for the improvement of egg production in Noi chickens.

In animals, dopamine (DA) plays an important role in regulating the physiological effects of the reproductive system such as creating excitement in mating. Besides, DA inhibits prolactin secretion through DRD2 in the pituitary gland. DRD2 gene functions to regulate and control the release of DA and 
Table 3 Association between polymorphic positions and Noi chicken egg production (egg/hen/20 laying weeks).

\begin{tabular}{|c|c|c|c|c|}
\hline SNP & Genotype & $\mathbf{n}$ & Egg production & $\mathbf{P}$ \\
\hline \multirow{3}{*}{ DRD2/BseGI } & TT & 1 & $26.0^{*}$ & \multirow{3}{*}{0.233} \\
\hline & $\mathrm{TC}$ & 27 & $50.7 \pm 3.9$ & \\
\hline & $\mathrm{CC}$ & 91 & $45.3 \pm 2.3$ & \\
\hline \multirow{3}{*}{ IGF-I/PstI } & $\mathrm{CC}$ & 6 & $47.0 \pm 9.3$ & \multirow{3}{*}{0.930} \\
\hline & $\mathrm{CT}$ & 27 & $43.9 \pm 4.4$ & \\
\hline & TT & 60 & $45.5 \pm 2.6$ & \\
\hline \multirow{3}{*}{ NPY/DraI } & II & 28 & $38.9 \pm 3.8^{\mathrm{b}}$ & \multirow{3}{*}{0.040} \\
\hline & ID & 55 & $48.7 \pm 2.9^{\mathrm{ab}}$ & \\
\hline & DD & 47 & $50.9 \pm 3.0^{\mathrm{a}}$ & \\
\hline \multirow{3}{*}{ NPY/KpnI } & TT & 25 & $43.4 \pm 4.2$ & \multirow{3}{*}{0.710} \\
\hline & $\mathrm{TC}$ & 62 & $47.8 \pm 3.0$ & \\
\hline & $\mathrm{CC}$ & 36 & $46.6 \pm 3.6$ & \\
\hline \multirow{3}{*}{$\mathrm{VIP} / H i n f \mathrm{I}$} & $\mathrm{CC}$ & 13 & $45.9 \pm 6.3$ & \multirow{3}{*}{0.130} \\
\hline & CT & 33 & $40.6 \pm 3.7$ & \\
\hline & TT & 61 & $49.9 \pm 2.8$ & \\
\hline \multirow{3}{*}{$\mathrm{VIP} / V s p \mathrm{I}$} & II & 69 & $46.6 \pm 2.6$ & \multirow{3}{*}{0.863} \\
\hline & ID & 47 & $47.3 \pm 3.1$ & \\
\hline & DD & 2 & $58.5 \pm 16.3^{*}$ & \\
\hline \multirow{3}{*}{ VIPR-1/TaqI } & $\mathrm{CC}$ & 53 & $49.8 \pm 2.7^{\mathrm{a}}$ & \multirow{3}{*}{0.045} \\
\hline & CT & 35 & $44.0 \pm 3.2^{\mathrm{ab}}$ & \\
\hline & TT & 21 & $37.7 \pm 4.5^{\mathrm{b}}$ & \\
\hline \multirow{3}{*}{ VIPR-1/HhaI } & $\mathrm{CC}$ & 78 & $50.4 \pm 2.2^{\mathrm{a}}$ & \multirow{3}{*}{0.047} \\
\hline & CT & 34 & $40.7 \pm 3.3^{b}$ & \\
\hline & TT & 9 & $42.9 \pm 6.7^{\mathrm{ab}}$ & \\
\hline
\end{tabular}

"Data were not subjected for statistical analysis; Values without common letters differ statistically at $P<0.05$.

thus mutations in the gene DRD2 may affect the reproductive performance of domestic chickens. The research by $\mathrm{Xu}$ et al. (2011b) revealed that DRD2/BseGI polymorphism affiliated with egg production of 300 days old, but this result was not supported by the present report.

Similarly, IGF-I gene had no effect on egg production of domestic chickens, despite its great contribution in stimulating growth, protein synthesis, cell proliferation and differentiation, egg development (McMurtry et al., 1997; Yun et al., 2005; Li et al., 2006;) and IGF-I/PstI has been proven to have correlation with egg production and days of continuous egglaying (Kim et al., 2004; Li et al., 2009).

VIP gene is also believed to be related to egg production of poultry due to its involvement in the synthesis and secretion of prolactin hormone by the pituitary gland. The mRNA concentration of VIP varies with hens' physiological status (Mauro et al., 1989; Chaiseha et al., 1998) and VIP enhances the stability of mRNA prolactin in vivo (Tong et al., 1998) as well. The activities that affect the VIP concentration in the body were suggested to influence the reproductive performance and hatching behavior (Caldwell et al., 1999). Zhou et al. (2010) found 69 polymorphisms when they studied 7 chicken breeds in China, among which AGG INDEL had significant effects on the total egg production during the period of 90-300 days old when chicken with D allele (with three nucleotides AGG inserted) yielded higher productivity. However, the percentage of DD genotype present in the surveyed population was very low $(1.2 \%)$. Results of the present study are in agreement with the finding of Zhou et al. (2010) that DD genotype proportion in Noi chickens was very low (1.7\%) and egg production averaged at 58.5 eggs/20 laying weeks/hen (the highest in all the genotypes studied). However, it was the average of only two individuals and would be just only for reference and no specific conclusions about the effect of this genotype in the population could yet be made.

\section{Conclusions}

In Noi chicken population, at each studied polymorphic locus two alleles existed with three different genotypes, including DRD2/BseGI, VIP/VspI and VIPR-1/HhaI with significant differences in allele distribution. Besides, genotypes at the NPY/DraI, VIPR-1/TaqI and VIPR-1/HhaI mutation points showed association with total egg production of laying Noi chickens of 20 laying weeks. These results provide an additional solution in the selection process towards improving egg production of Noi chicken. 


\section{Acknowledgment}

This project was completed with the support of the Ministry of Education and Training of Vietnam, code B2013-16-27.

\section{Conflict of interest}

Authors would hereby like to declare that there is no conflict of interests that could possibly arise.

\section{References}

Abdi M, Seyedabadi H, Gorbani A (2014) Prolactin and NPY Gene Polymorphism and its Associations with Production and Reproductive traits in West-Azarbaijan Native chicken. Bulletin of Environment, Pharmacology and Life Sciences 3: $39-45$.

Abbasi HA, Kazemi M (2011) Detection of polymorphism at the Insulin Like Growth Factor-I gene in Mazandaran native chicken using Polymerase Chain Reaction-Restriction Fragment Length Polymorphism method. American Journal of Animal and Veterinary Sciences $6: 80-83$. doi : 10.3844/ajavsp.2011.80.83.

Caldwell SR, Johnson AF, Yule TD, Grimes JL, Ficken M, Christensen VL (1999) Increased egg production in juvenile turkey hens after active immunization with vasoactive intestinal peptide. Poultry Science 78: 899-901.

Chaiseha Y, Tong Z, Youngren OM, El Halawani ME (1998) Transcriptional changes in hypothalamic vasoactive intestinal peptide during a photoinduced reproductive cycles in the turkey. Journal of Molecular Endocrinology 21: 267-275. doi: 10.1677/jme.0.0210267.

Chaiseha Y, Youngren O, Al-Zailaie K, Halawani M (2003) Expression of D1 and D2 dopamine receptors in the hypothalamus and pituitary during the turkey reproductive cycle: colocalization with vasoactive intestinal peptide. Neuroendocrinology 77: 105-118. doi:10.1159/000068649.

Christian CA, Moenter SM (2008) Vasoactive intestinal polypeptide can excite gonadotropin-releasing hormone neurons in a manner dependent on estradiol and gated by time of day. Endocrinology 149: 3130-3136. doi: 10.1210/en.20071098.

Dunn IC, Miao YW, Morris A, Romanov MN, Wilson PW, Waddington D (2004) A study of association between genetic markers in candidate genes and reproductive traits in one generation of a commercial broiler breeder hen population. Heredity 92: 128-134. doi:10.1038/sj.hdy.6800396.

El Halawani ME, Whiting SE, Silsby JL, Pitts GR, Chaiseha Y (2000) Active immunization with vasoactive intestinal peptide in turkey hens. Poultry Science 79: 349-354. doi: 10.1093/ps/79.3.349.

Journal of Experimental Biology and Agricultural Sciences http://www.jebas.org
Fatemi SA, Mehrabani-Yeganeh H, Nejati-Javaremi A, Niknafs SH (2012) Association of Neuropeptide Y and gonadotrophin-releasing hormone receptor gene SNPs with breeding value for growth and egg production traits in Mazandaran native chickens. University of Telhran, Karaj, Iran.

Hilal EM, Chen JH, Silverman AJ (1996) Join migration of gonaldotropin-releasing hormone $(\mathrm{GnRH})$ and neuropeptide $\mathrm{Y}$ (NPY) neurons from olfactory placode to central nervous system. Journal of Neurobiology 31: 487-502.

Kim MH, Seo DS, Ko Y (2004) Relationship between egg productivity and insulin-like growth factor-I genotypes in Korean native Ogol chickens. Poultry Science 83: 1203-1208. doi: 10.1093/ps/83.7.1203.

Kuenzel WJ, McMurtry J (1988) Neuropeptide Y: brain localization and central effects on plasma insulin levelsin chicks. Physiology \& Behavior 44: 669-678. doi:10.1016/0031-9384(88)90334-4.

Li HF, Zhu WQ, Chen KW, Wu X, Tang QP, Gao YS, Song WT, Xu WJ, Xu HL (2009) Polymorphism in NPY and IGF-I genes associate with reproductive traits in Wenchang chicken. African Journal of Biotechnology 8: 4744-4748.

Li ZH, Li H, Zhang H, Wang SZ, Wang QG, Wang YX (2006) Identification of a single nucleotide polymorphism of the insulin-like growth factor binding protein 2 gene and its association with growth and body composition traits in the chicken. Journal of Animal Science 84: 2902-2906. doi:10.2527/jas.2006-144.

Mauro LJ, Elde RP, Youngren OM, Phillips RE, El Halawani ME (1989) Alterations in hypothalamic vasoactive intestinal peptide-like immunoreactivity are associated with reproduction and prolactin release in the female turkey. Endocrinology 125:1795-1804. http://dx.doi.org/10.1210/endo-125-4-1795.

McMurtry JP, Francis GL, Upton Z (1997) Insulin-like growth factors in poultry. Domestic Animal Endocrinology 14: 199229. doi:10.1016/S0739-7240(97)00019-2.

Nagaraja SC, Aggrey SE, Yao J, Zadworny D, Fairfull RW, Kuhnlein U (2000) Trait association of a genetic marker near the IGF-I gene in egg-laying chickens. Journal of Heredity 91: 150-156. doi: 10.1093/jhered/91.2.150.

Nozawa H, Yamamoto T, Uchihi R, Yoshimoto T, Tamaki K, Hayashi S, Ozawa T Katsumata Y (1999) Purification of nuclear DNA from single hair shafts for DNA analysis in forensic sciences. Legal Medicine 1: 61-67. DOI: http://dx.doi.org/10.1016/S1344-6223(99)80014-5.

Quyen NV, Son VV (2008) Effects of metalizable energy levels and crude protein to reproductive performance of Noi 
chiken in the Mekong Delta (In Vietnamese). Journal of Animal Husbandry Sciences and Techniques 2: 19-25.

Solé X, Guinó E, Valls J, Iniesta R, Moreno V (2006) SNPStats: a web tool for the analysis of association studies. Bioinformatics 22: 1928-1929. doi: 10.1093/bioinformatics/bt1268.

Tong Z, Pitts GR, You S, Foster DN, El Halawani ME (1998) Vasoactive intestinal peptide stimulates tureky prolactin gene expression by increasing transcription rate and enhancing mRNA stability. Journal of Molecular Endocrinology 21: 259266. doi: 10.1677/jme.0.0210259.

Willoughby JO, Blessing WW (1987) Neuropeptide Y injected into the supraoptic nucleus causes secretion of vasopressin in the unanesthetized rat. Neuroscience Letter 75: 17-22. doi:10.1016/0304-3940(87)90068-1.

Xu H, Shen X, Zhou M, Fang M, Zeng H, Nie Q, Zhang X (2010) The genetic effects of the dopamine D1 receptor gene on chicken egg production and broodiness traits. BMC Genetics 11:17. doi: 10.1186/1471-2156-11-17.

Xu H, Zeng H, Luo C, Zhang D, Wang Q, Sun L, Yang L, Zhou M, Nie Q, Zhang X (2011a) Genetic effects of polymorphisms in candidate gens and the QTL region on chicken age at first egg. BMC Genetics 12:33. doi: 10.1186/1471-2156-12-33.

Xu HP, Zeng H, Zhang DX, Jia XL, Luo CL, Fang MX, Nie QH, Zhang XQ (2011b) Polymorphisms associated with egg number at 300 days of age in chickens. Genetics and Molecular Research 10 : 2279-2289. DOI: 10.4238/2011.October.3.5

Yun JS, Seo DS, Kim WK, Ko Y (2005) Expression and relationship of the insulin-like growth factor system with posthatch growth in the Korean Native Ogol chicken. Poultry Science 84: 83-90. doi: 10.1093/ps/84.1.83.

Zhou M, Du Y, Nie Q, Liang Y, Luo C, Zeng H, Zhang X (2010) Associations between polymorphisms in the chicken VIP gen, egg production and broody traits. British Poultry Science 51: 195-203. doi: 10.1080/00071661003745786.

Zhou M, Lei M, Rao Y, Nie Q, Zeng H, Xia M, Liang F, Zhang D, Zhang X (2008a) Polymorphisms of asoactive peptide receptor- 1 gene and their genetic effects on broodiness in chickens. Poultry Science 87: 893-903. doi: 10.3382/ps.2007-00495.

Zhou M, Liang F, Rao Y, Zeng H (2008b) Association of twelve polymorphisms of the VIPR-1 gene with chicken early egg production traits. Chinese Journal of Animal and Veterinary Sciences 39: 1147-1152. 